\title{
Preliminary Evaluation of Rainbow Trout Diets Containing PepSoyGen, a Fermented Soybean Meal Product, and Additional Amino Acids
}

\author{
Michael E. Barnes ${ }^{1, *}$, Michael L. Brown ${ }^{2}$, Kurt A. Rosentrater $^{3}$ and Jason R. Sewell ${ }^{4}$ \\ ${ }^{I}$ McNenny State Fish Hatchery, South Dakota Department of Game, Fish and Parks, 19619 Trout Loop, Spearfish, \\ South Dakota USA 57783 \\ ${ }^{2}$ Department of Wildlife and Fisheries Sciences, South Dakota State University, Brookings, South Dakota USA 57007 \\ ${ }^{3}$ Iowa State University, Department of Agricultural and Biosystems Engineering, Ames, Iowa USA 50011 \\ ${ }^{4}$ Nutraferma Inc., North Sioux City, South Dakota USA 57049
}

\begin{abstract}
Juvenile rainbow trout Oncorhynchus mykiss diets containing PepSoyGen, a commercially-available fermented soybean meal product, were supplemented with methionine and other amino acids. A fish meal-based control and four experimental diets were used in a 36-day feeding trial; two diets contained $40 \%$ PepSoyGen and $10 \%$ fish meal, and two diets contained 50\% PepSoyGen and no fish meal. Each of these diets was supplemented with either methionine, or methionine and additional amino acids. One mortality was observed during the trial. Overall weight gain, percent gain, and feed conversion ratio were significantly greater for the fish meal control than for any of the PepSoyGen diets, although feed conversion ratios from all of the diets were still below 1 . Apparent protein digestibility was significantly less in the fish receiving the control diet compared to any of the experimental diets, and significantly increased with increasing PepSoyGen concentrations. There was no significant difference in length, weight, condition factor, hepatosomatic index, viscerosomatic index, or any fish health responses among dietary treatments. Fillet composition, as determined by crude protein, crude lipid, water, and ash, was also not significantly different among fish reared on any of the diets. The supplementation of other amino acids in addition to methionine had no noticeable effect. The results from this study indicate that PepSoyGen with amino acid supplementation can completely replace fish meal in juvenile rainbow trout grower diets over a relatively short time-frame, albeit with some decrease in rearing performance.
\end{abstract}

Keywords: Alternative proteins, diets, fermented soybean meal, fish meal, Oncorhynchus mykiss, PepSoyGen, rainbow trout.

\section{INTRODUCTION}

There is an abundance of research on the use of various soybean meal products in rainbow trout diets [1]. However, primarily because of the presence of numerous anti-nutritional factors [2-5] and negative effects on intestinal form and function [5-12], soybean meal inclusion in trout diets is limited.

The use of heat, pressure, chemical treatments, and other processes on soybean meal has reduced or eliminated many of the undesirable effects and anti-nutritional factors $[4,13-$ 16]. Biological fermentation may also improve the suitability of soybean meal as an alternative protein source in trout diets. Although fermented soybean meal has been used successfully in the diets of a variety of vertebrate animals [1719], few studies have been conducted with fish in general or rainbow trout specifically until very recently. Fermented soybean meal has been used in the diets of parrot fish Oplegnathus fasciatus [20], red sea bream Pagrus major [21], pompano Trachinotus ovatus [22], and Japanese floun

*Address correspondence to this author at the McNenny State Fish Hatchery, South Dakota Department of Game, Fish and Parks, 19619 Trout Loop, Spearfish, South Dakota USA 57783; Tel: 605-642-1262,

Fax:605-642-6921; E-mail: Mike.Barnes@state.sd.us der Paralichthys olivaceus [23, 24]. Yamamoto et al. [25] noted that soybean meal fermented for $10 \mathrm{~h}$ with $30 \%$ water addition did not cause any changes in intestinal morphology when used in non-fish meal rainbow trout diets, whereas less-fermented soybean meal in the diet did cause the typically-observed intestinal morphological effects. Yamamoto et al. [25] stated that fermented soybean meal had the potential to be the predominant protein source in rainbow trout diets.

Recently, a soybean meal fermentation product manufactured via a proprietary process incorporating Aspergillus spp. and Bacillus sp. has been developed (PepSoyGen, Nutraferma Inc., North Sioux City, South Dakota, USA). Although it may not contain enough methionine to meet the dietary requirements of rainbow trout [26], it may be suitable as a protein source with amino acid supplementation. It may also have potential advantages with the inclusion of probiotic bacteria as part of the manufacturing process [12]. Thus, the objective of this preliminary study was to examine the use of PepSoyGen with amino acid supplementation in the diets of juvenile rainbow trout.

\section{MATERIALS AND METHODOLOGY}

The trial occurred at McNenny State Fish Hatchery, Spearfish, South Dakota, USA, using degassed and aerated 
Table 1. Percent Composition and Chemical Analysis of the Diets Used in the Trial

\begin{tabular}{|c|c|c|c|c|c|}
\hline Diet & 1 & 2 & 3 & 4 & 5 \\
\hline Amino acid supplementation & none & methionine & multiple & methionine & multiple \\
\hline \multicolumn{6}{|c|}{ Ingredients } \\
\hline Menhaden meal ${ }^{\text {a }}$ & 40.0 & 10.0 & 10.0 & 0.0 & 0.0 \\
\hline PepSoyGen ${ }^{\text {b }}$ & 0.0 & 40.0 & 40.0 & 50.0 & 50.0 \\
\hline Yellow corn gluten ${ }^{d}$ & 25.0 & 21.0 & 19.0 & 20.0 & 19.0 \\
\hline Menhaden oil ${ }^{\mathrm{e}}$ & 11.5 & 14.1 & 14.1 & 14.9 & 14.9 \\
\hline $\mathrm{CMC}^{\mathrm{f}}$ & 0.6 & 0.0 & 0.0 & 0.0 & 0.6 \\
\hline Vitamin premix ${ }^{\mathrm{g}}$ & 0.5 & 0.5 & 0.5 & 0.5 & 0.5 \\
\hline L-Lysine $^{\mathrm{k}}$ & 0.0 & 0.0 & 0.5 & 0.0 & 0.5 \\
\hline L-Isoleucine ${ }^{k}$ & 0.0 & 0.0 & 0.3 & 0.0 & 0.3 \\
\hline L-Histidine $^{\mathrm{k}}$ & 0.0 & 0.0 & 0.1 & 0.0 & 0.1 \\
\hline L-Methionine ${ }^{\mathrm{k}}$ & 0.0 & 0.5 & 0.5 & 0.5 & 0.5 \\
\hline Sodium chloride & 0.5 & 0.9 & 0.9 & 0.9 & 0.9 \\
\hline Potassium chloride & 0.6 & 0.7 & 0.7 & 0.7 & 0.7 \\
\hline Magnesium oxide & 0.0 & 0.1 & 0.1 & 0.1 & 0.1 \\
\hline Calcium phosphate & 0.0 & 2.3 & 2.3 & 2.3 & 2.3 \\
\hline DE (MJ/kg dry matter) & 14.92 & 14.35 & 14.75 & 14.32 & 15.07 \\
\hline
\end{tabular}

${ }^{\mathrm{a}}$ IPC 740, Scoular, Minneapolis, Minnesota, USA

${ }^{\mathrm{b}}$ Nutra-flo Protein and Biotech Products, Sioux City, Iowa, USA.

' Bob's Red Mill Natural Foods, Milwaukie, Oregon, USA.

${ }^{\mathrm{d}}$ Consumers Supply Distributing, Sioux City, Iowa, USA.

${ }^{\mathrm{e}}$ Omega Protein, Inc., Houston, Texas, USA.

${ }^{\mathrm{f}}$ Carboxymethyl cellulose, USB Corporation, Cleveland, Ohio, USA

${ }^{g}$ ARS 702, Barrows et al. 2008, Nelson and Sons, Inc., Murray, Utah, USA.

${ }^{\mathrm{h}}$ ARS 640, Barrows et al. 2008, Nelson and Sons, Inc., Murray, Utah, USA.

${ }^{i}$ DSM Nutritional Products France SAS, Village-Neuf, France.

${ }^{j}$ Diamond V, Cedar Rapids, Iowa, USA.

${ }^{k}$ PureBulk, Roseburg, Oregon, USA

${ }^{1}$ Analysis conducted on post-extrusion pellets.

well water at a constant temperature of $11^{\circ} \mathrm{C}$ (total hardness as $\mathrm{CaCO}_{3}, 360 \mathrm{mg} / \mathrm{L}$; alkalinity as $\mathrm{CaCO}_{3}, 210 \mathrm{mg} / \mathrm{L} ; \mathrm{pH}$, 7.6; total dissolved solids, $390 \mathrm{mg} / \mathrm{L}$ ). Flows in each tank were set at $40 \mathrm{~L} / \mathrm{min}$. Shasta strain rainbow trout (initial weight $33.6 \pm 1.5 \mathrm{~g}$, length $146.7 \pm 2.1 \mathrm{~mm}$, mean $\pm \mathrm{SE})$ were placed into each of 15 fiberglass circular tanks $(1.8 \mathrm{~m}$ diameter, $0.6 \mathrm{~m}$ depth) on September 2, 2010. Tanks were each loaded with 40 fish, and total tank weights were recorded to the nearest gram. Feeding commenced the following day and continued for 36 days until the end of the trial. Feeding amounts for the tanks were determined by the hatchery constant method [27], with a planned feed conversion of 1.1 and a maximum growth rate of $0.066 \mathrm{~cm} /$ day, which was determined from the historical performance of the Shasta strain at McNenny State Fish Hatchery. Ration amounts were updated daily. Fish were hand fed once per day. All feed fed and fish deaths were recorded daily for each tank.

The 15 tanks were randomly assigned to one of five different diets (Table 1), with three replicate tanks per treatment group. In addition to a fish meal-based control, four other 
Table 2. Amino Acid Composition (\%, Dry Weight) of the Diets, and the Fermented Soybean Meal Product (PepSoyGen), Used in the Trial

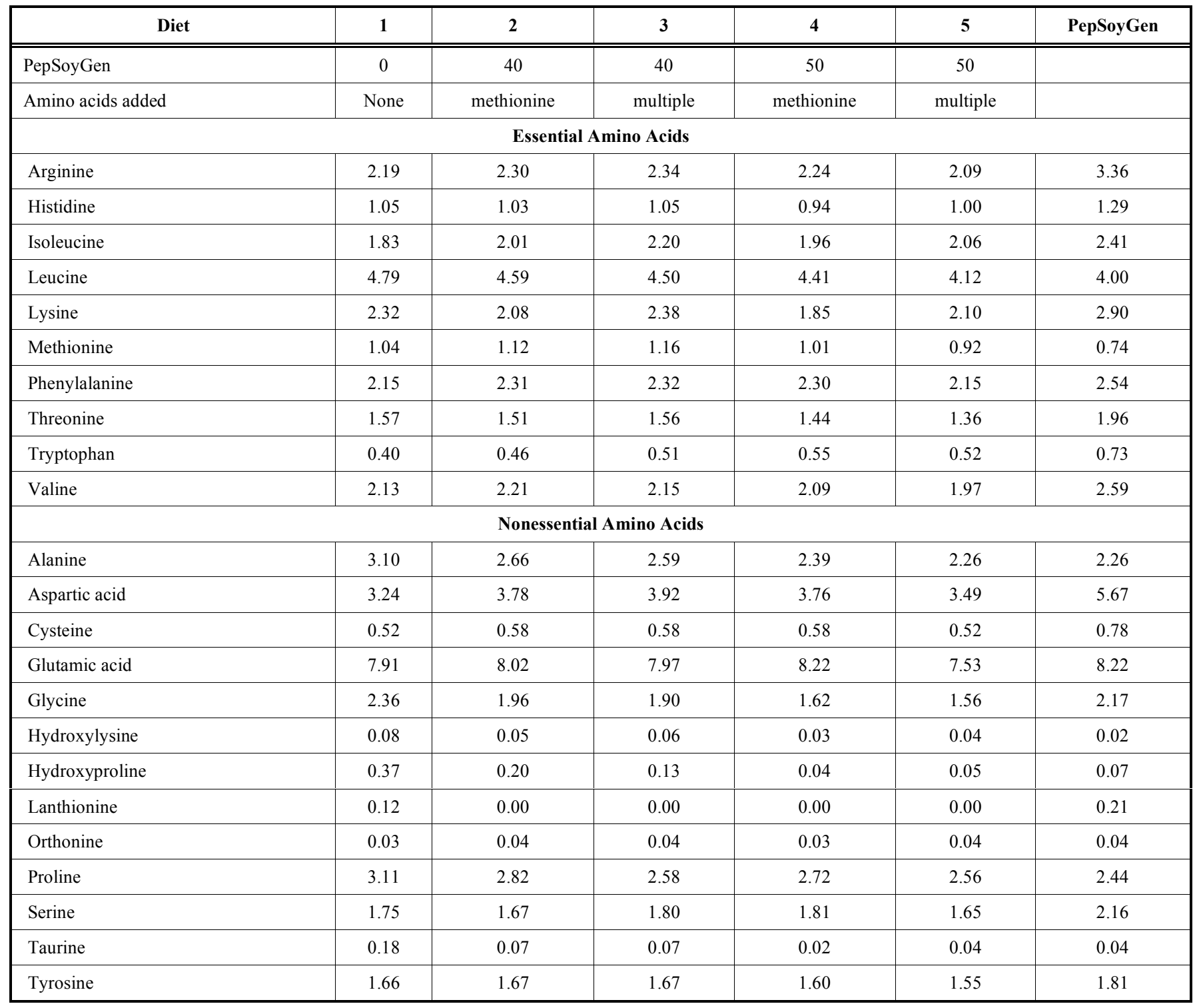

diets contained the commercially-produced PepSoyGen product $(51.3 \%$ protein, $1.2 \%$ fat, and $2.6 \%$ fiber). Two of these diets contained $10 \%$ fish meal and $40 \%$ PepSoyGen, and two diets contained only 50\% PepSoyGen (Table 2). To compensate for an anticipated methionine-deficiency in the PepSoyGen diets, methionine was added to all of the experimental diets. In addition, lysine, isoleucine, and histidine were also added to one of the $40 \%$ and one of the $50 \%$ PepSoyGen diets to match the essential amino acid profile of the fish meal control. The amino acid composition of each of the diets and PepSoyGen is listed in Table 2. Experimental diets were analyzed according to AOAC [28] methodology for amino acids (method 982.30), protein (method 2001.11) and crude lipid (method 2003.5, modified by substituting petroleum ether for diethyl ether), and for ash content by AACC [29] method 08-03. The protein and lipid amounts obtained by these methods were multiplied by their respective physiological fuel values of 23.6 and 39.5 [26] to obtain estimated digestible energy values.
At the end of the trial, total tank weights were recorded to the nearest g, with weight gain calculated by subtracting the initial weight from the final weight for each tank. Feed conversion ratio for each tank was calculated by dividing the total amount of food fed by the total weight gain. In addition to total tank measurements, five fish from each tank were randomly selected from each tank and individually weighed to the nearest $g$ and measured (total length) to the nearest $\mathrm{mm}$. Fish health profiles for these sampled fish, based on a modification of Goede and Barton [30], Adams et al. [31], and Barton et al. [32], were completed using the score sheet described in Table 3. Liver weights were recorded to the nearest $\mathrm{mg}$ and the hepatosomatic index (HSI) determined using the formula: HSI $(\%)=100 \times$ (liver weight/whole fish weight) [33]. Viscera weights were also recorded to the nearest $\mathrm{mg}$ and the viscerosomatic index (VSI) determined using the formula: VSI $(\%)=100 \times$ (viscera weight/whole fish weight). 
Table 3. Criteria Used at the End of the Study for Fish Health Observations [Based on Goede and Barton [30], Adams et al. [31], and Barton et al. [32]]

\begin{tabular}{|c|c|c|}
\hline Structure or Tissues & Rating Criteria & Numeric Rating \\
\hline Gills & $\begin{array}{c}\text { Normal } \\
\text { Clubbed, frayed, or discolored }\end{array}$ & $\begin{array}{l}0 \\
1\end{array}$ \\
\hline Kidney & $\begin{array}{c}\text { Normal } \\
\text { Abnormal }\end{array}$ & $\begin{array}{l}0 \\
1\end{array}$ \\
\hline Liver & $\begin{array}{c}\text { Normal } \\
\text { Abnormal }\end{array}$ & $\begin{array}{l}0 \\
1\end{array}$ \\
\hline Pseudobranchs & $\begin{array}{c}\text { Normal } \\
\text { Abnormal }\end{array}$ & $\begin{array}{l}0 \\
1\end{array}$ \\
\hline Opercles & $\begin{array}{l}\text { Normal } \\
\text { Short }\end{array}$ & $\begin{array}{l}0 \\
1\end{array}$ \\
\hline
\end{tabular}

Apparent protein digestability was determined using a direct method [34]. Digesta was removed from five fish per tank at the end of the trial. Each fish was dissected and the last $\mathrm{cm}$ of the distal end of the intestine was gently squeezed to remove the contents. Digesta from five fish per tank was pooled and flash frozen on dry ice prior to analysis. Protein analysis was conducted using AOAC [28] method 990.03. Apparent protein digestability was calculated using the formula: apparent protein digestability $=$ (protein in the diet protein in the digesta) / protein in the diet.

At the end of the experiment, five whole fish per tank were euthanized; muscle fillets were then removed and flash frozen for determination of carcass composition. The fillets from each tank were pooled and analyzed for crude protein levels with a TruSpec CNS combustion analyzer (LECO Corp., St. Joseph, Michigan, USA) using AOAC [28] method 992.15. AOAC [28] acid hydrolysis method 948.15 with a 50:50 mix of diethyl ether and petroleum ether for extraction was used for fat analysis, and moisture was determined by drying loss using AOAC [28] method 952.08.

Data were analyzed using the SPSS (9.0) statistical analysis program (SPSS, Chicago, Illinois, USA) with significance predetermined at $P<0.05$. One-way analysis of variance (ANOVA) was conducted and if the treatments were significantly different, mean comparisons were performed using the Tukey HSD test [35]. All percentage data were arcsine transformed prior to analysis to stabilize the variances [35].

\section{RESULTS}

Overall weight gain and percent weight gain were significantly greater in the control diet compared to any of the diets containing PepSoyGen $(P=0.001$ and 0.007 , respectively, Table 4). Feed conversion ratio was significantly less in the control diet compared to any of the PepSoyGen diets $(P=0.001)$, but the feed conversion ratios for all of the diets were below 1. Apparent protein digestibility was significantly lower $(\mathrm{P}<0.001)$ for the control $\operatorname{diet}(91.4 \%)$, than the $93.2 \%$ and $93.3 \%$ values in the fish receiving either of the diets containing $40 \%$ PepSoyGen, which in turn were significantly less than that observed in fish fed either of the $50 \%$ PepSoyGen diets. Only one mortality was observed during the trial.

Individual fish measurements were very similar among the diets (Table 5). There were no significant differences in individual fish lengths, weights, or condition factors among the treatment groups. Although liver weights were significantly less $(P=0.018)$ in the fish receiving any of the 
Table 4. Total Tank Rearing Data (mean \pm SE), Including Feed Conversion Ratio and Apparent Protein Digestibility, for Tanks of Rainbow Trout Receiving one of Five Different Diets Containing Either 40 or $50 \%$ PepSoyGen, with or without Methionine and Additional Amino Acids. Means in a Row with Different Letters are Significantly Different $(N=3, P<0.05)$.

\begin{tabular}{|c|c|c|c|c|c|}
\hline Diet & $\mathbf{1}$ & $\mathbf{2}$ & $\mathbf{3}$ & $\mathbf{4}$ & 50 \\
\hline \hline PepSoyGen (\%) & 0 & 40 & 40 & 50 \\
\hline Amino acid supplementation & none & methionine & multiple & methionine & multiple \\
\hline Start weight (g) & $1,218 \pm 45$ & $1,240 \pm 68$ & $1,276 \pm 49$ & $1,235 \pm 51$ & $1,285 \pm 32$ \\
\hline End weight (g) & $2,229 \pm 44$ & $2,150 \pm 90$ & $2,185 \pm 76$ & $2,084 \pm 54$ & $2,171 \pm 36$ \\
\hline Gain (g) & $1,011 \pm 10 \mathrm{z}$ & $910 \pm 23 \mathrm{y}$ & $909 \pm 28 \mathrm{y}$ & $849 \pm 4 \mathrm{y}$ & $886 \pm 8 \mathrm{y}$ \\
\hline Gain (\%) & $83.2 \pm 3.2 \mathrm{z}$ & $73.7 \pm 2.5 \mathrm{y}$ & $71.3 \pm 0.9 \mathrm{y}$ & $69.0 \pm 2.6 \mathrm{y}$ & $69.0 \pm 1.5 \mathrm{y}$ \\
\hline Food fed (g) & 834 & 834 & 834 & 834 & $0.98 \pm 0.01 \mathrm{y}$ \\
\hline Feed conversion ratio & $0.82 \pm 0.01 \mathrm{z}$ & $0.92 \pm 0.01 \mathrm{y}$ & $0.92 \pm 0.03 \mathrm{y}$ & $0.94 \pm 0.01 \mathrm{y}$ \\
\hline Mortality (\%) & $0.0 \pm 0.0$ & $0.0 \pm 0.0$ & $0.0 \pm 0.0$ & $0.3 \pm 0.3$ & $0.0 \pm 0.0$ \\
\hline Apparent protein digestibility & $91.4 \pm 0.2 \mathrm{z}$ & $93.3 \pm 0.4 \mathrm{y}$ & $93.2 \pm 0.4 \mathrm{y}$ & $94.7 \pm 0.1 \mathrm{x}$ & $95.2 \pm 0.3 \mathrm{x}$ \\
\hline
\end{tabular}

Table 5. Ending mean ( \pm SE) Length, Weights, Condition Factors $(K)^{a}$, Viscera Weight, Viscerosomatic Index ${ }^{b}$, Liver Weight, Hepatosomatic Index Values ${ }^{c}$, and Fish Health Assessments ${ }^{d}$ for Rainbow Trout Fed Diets Containing Either 40 or $50 \%$ PepSoyGen with Methionine and Additional Amino Acids. Means with Different Letters Across a Row are Significantly Different $(N=3, P<0.05)$

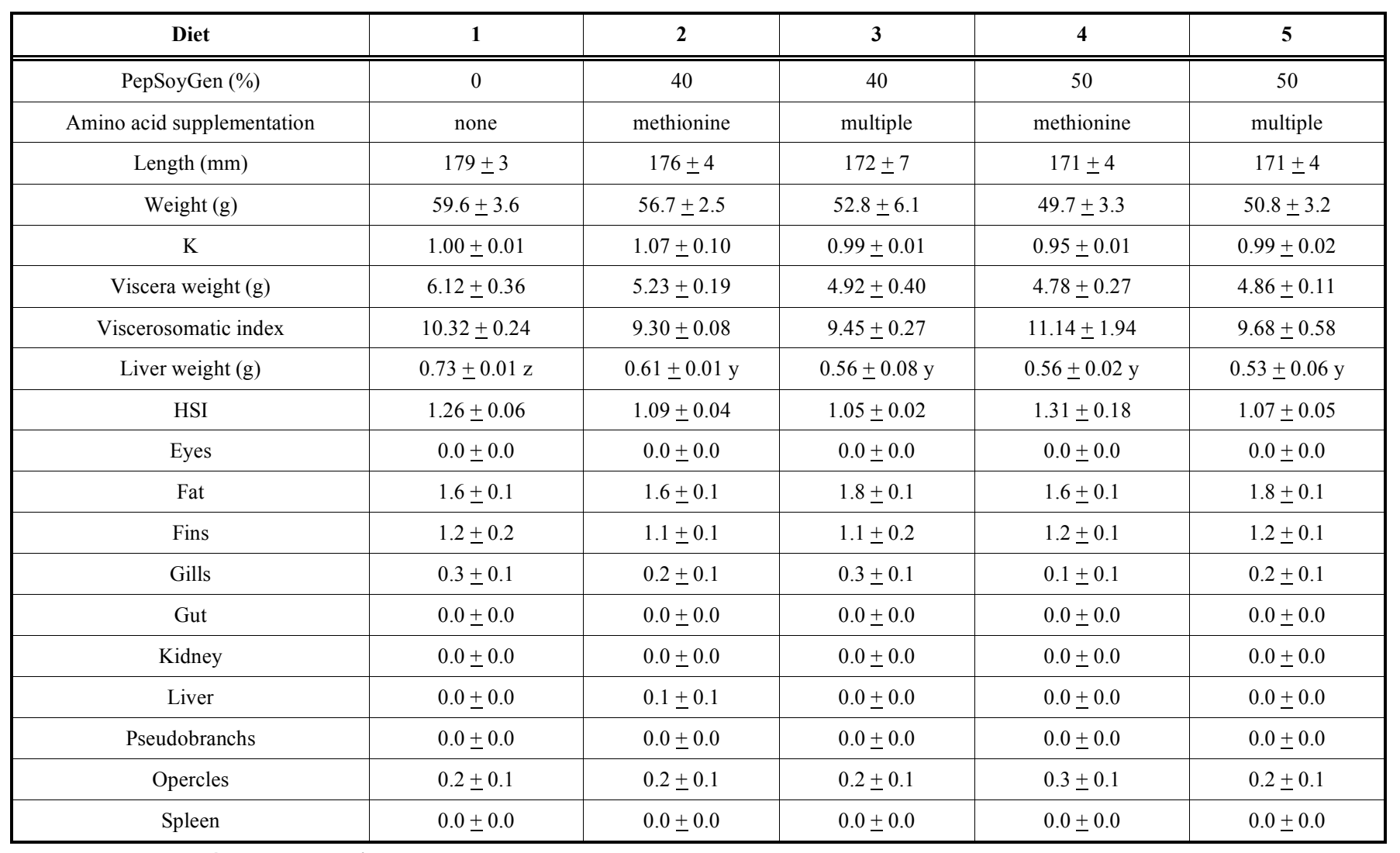

${ }^{a}$ Condition factor $(\mathrm{K})=10^{5} \mathrm{x}$ (weight) $/\left(\right.$ length $\left.^{3}\right)$

${ }^{\mathrm{b}}$ Viscerosomatic index (VSI)m $=100 \mathrm{x}$ (viscera weight/body weight)

${ }^{\mathrm{C}}$ Hepatosomatic index $(\mathrm{HSI})=100 \mathrm{x}$ (liver weight/body weight)

${ }^{\mathrm{d}}$ Fish health assessments rating system described in Table $\mathbf{2}$.

PepSoyGen diets, there was no significant difference in the hepatosomatic index. The viscerosomatic index was also not significantly different among the diets. None of the fish health values varied significantly among the fish receiving any of the diets, and no gross visual gut inflammation was observed in any fish.

Fillet composition was not significantly affected by any of the diets used in this study (Table 6). Fillet protein per- 
Table 6. Mean $( \pm$ SE) Percent Water, Crude Protein, Crude Lipid, and ash Concentrations from Fillets of Rainbow Trout fed Diets Containing Either 40 or 50\% PepSoyGen, with Methionine and Additional Amino acids $(\mathbf{N}=3)$. There were no Significant Differences Among the Treatment Groups $(P<0.05)$

\begin{tabular}{|c|c|c|c|c|c|}
\hline Diet & 1 & 2 & 3 & 4 & 5 \\
\hline PepSoyGen (\%) & 0 & 40 & 40 & 50 & 50 \\
\hline Amino acid supplementation & none & methionine & multiple & methionine & multiple \\
\hline Water (\%) & $77.3 \pm 0.9$ & $75.1 \pm 0.1$ & $76.1 \pm 0.2$ & $75.9 \pm 0.2$ & $75.9 \pm 0.4$ \\
\hline Crude protein (\%) & $18.6 \pm 0.3$ & $18.6 \pm 0.3$ & $19.4 \pm 0.3$ & $19.2 \pm 0.2$ & $19.4 \pm 0.1$ \\
\hline Crude lipid (\%) & $4.6 \pm 0.1$ & $5.3 \pm 0.3$ & $4.2 \pm 0.4$ & $4.4 \pm 0.4$ & $4.8 \pm 0.3$ \\
\hline Ash (\%) & $1.5 \pm 0.1$ & $1.5 \pm 0.1$ & $1.4 \pm 0.1$ & $1.4 \pm 0.1$ & $1.5 \pm 0.1$ \\
\hline
\end{tabular}

centages ranged from a low of $18.6 \%$ in fish fed the fish meal control to $19.4 \%$ in fish receiving feed with $50 \%$ PepSoyGen. Mean fillet lipid contents were also very similar among the diets.

\section{DISCUSSION}

The reductions in weight gain and increases in feed conversion ratio of fish fed diets containing the commercial PepSoyGen product in the present study cannot be directly compared to Yamamoto et al. [25], who noted no difference in final body weight and gain between their fish meal control and one of their PepSoyGen diets. Although the experimental diets in both studies were similar, Yamamoto et al. [25] fed fish to satiation, focused only on growth, and did not report feed conversion ratios. In contrast, this study used a production-based feeding model based on well-established feeding rates [36] in an attempt to eliminate the possible confounding effect of unregulated feeding [37]. It is possible that increasing feeding rates for the fish receiving PepSoyGen may have produced similar growth rates with the fish meal-based control diet, although feed conversion ratios would likely have been much greater. Yamamoto et al. [25] also supplemented their PepSoyGen diets with four amino acids (arginine, threonine, tryptophan, and valine) not included in this study. However, none of these four amino acids, nor any essential amino acids, were below the critical values listed by the National Research Council [26] in any of the diets used in the present study. The study by Yamamoto et al. [25] was also conducted in much warmer water $\left(16.3^{\circ} \mathrm{C}\right)$ than this study. Other studies evaluating different dietary ingredients have indicated a possible influence of water temperature on feed conversion ratio [38, 39], weight gain $[38,39]$, and nutrient digestibility $[40,41]$.

Although specific feeding trial durations are not universally specified, they generally need to last long enough for any potential significant differences among the diets to materialize [42]. In a study by de Francesco et al. [43] differences in trout rearing performance between fish meal and plantbased diets did not become apparent until after 12 weeks. The present study lasted only 36 days, but this was sufficient for significant differences in gain and feed conversion ratio to appear among the dietary treatments. It is unlikely that prolonging this trial for a longer period would have produced different results. However, given the small sample sizes used in this study, it is possible that additional replication may have produced different results.
At only $0.74 \%$, the PepSoyGen used in this study is relative low in methionine in relation to the dietary requirements of rainbow trout diets [26]. This is not unexpected, as soybean meal typically does not contain enough methionine to meet the nutritional requirements of rainbow trout [1, 44]. Methionine has been supplementated in other studies using soybean meal or soy protein concentrates fed to rainbow trout $[5,9,45]$. Incorporating other amino acids in addition to methionine did lead to an increase in the percentage of these amino acids in the diets, but appeared to provide no noticeable improvement to any of the parameters studied.

Feed conversion ratios below 1.0 are not unusual for rainbow trout reared at production hatcheries in South Dakota [36] or elsewhere [46]. The 0.82 feed conversion ratio for fish fed the control diet was at the low end of that reported by Barrows et al. [47] for their fish meal-based control diets. Even though the feed conversion ratios for the PepSoyGen diets were higher than the control, they were still less than those reported by Cheng et al. [48, 49] for rainbow trout fed soybean-free, fish meal-based diets, as well as diets containing soybean meal. All of the feed conversion ratios from the fermented soybean-meal-containing diets were similar to a commercial fish meal-based control diet used in a study by Adelizi et al. [45]. The relatively low rearing densities used in this trial may also have influenced the observed feed conversion ratios $[50,51]$.

The apparent protein digestibilities observed in this study are very similar to those reported by Yamamoto et al. [25] for rainbow trout receiving diets with fermented soybean meal. The positive relationship between dietary PepSoyGen concentrations and protein digestibility in the current study does not follow the pattern of decreased digestibilities associated with soybean meal inclusion in rainbow trout diets [44]. The fermentation process of the PepSoyGen product used in this study hydrolyzes the long chain proteins into small chain proteins allowing them to be more digestible for young animals (relative to de-hulled soybean meal and other soy proteins). The fermentation process also reduces indigestible oligosaccharides (raffinose and stachyose) and trypsin inhibitor that can have a negative influence on nutrient digestibility. Overall, the protein digestibilities in the current study are much higher than that reported by Refstie et al. [52] for both fish meal control and 60\% soybean meal diets, and similar to those from Cheng et al. [48] and Kaushik et al. [53] for rainbow trout receiving diets with low concentrations of soybean meal or other soybean-based products. It 
can be difficult to compare digestibilities among studies [26], and it is possible that the different fecal collection methods used in these studies may have influenced the assessment of protein digestibility as well [34, 42, 54, 55].

None of the diets in this study produced any observable deleterious effects on fish health. In particular, no gross inflammation of the distal intestines of the fish receiving dietary PepSoyGen was observed in this study. However, microscopic examination did not occur. Yamamoto et al. [25] noted that lengthy and moist fermentation of soybean meal using Bacillus sp. could eliminate the occurrence of physiological abnormalities typically observed with the use of soybean meal in salmonid diets. The process by which PepSoyGen is manufactured reduces or eliminates a variety of antinutritional factors that can negatively impact fish health in general, and intestinal health specifically. It is also possible that as a result of the fermentation process, PepSoyGen may also contain immunomodulatory components $[20,23,56]$.

Although HSI is positively related to dietary carbohydrate levels [57, 58], there was no difference in HSI among any of the diets. Because dietary phosphorus is inversely related to liver lipid levels and HSI [59], the lack of difference in HSI among the diets would appear to indicate no deficiencies in phosphorus availability from any of the diets. The HSI values in the current study were similar to those reported from rainbow trout receiving fish meal-based diets $[45,47]$ but lower than those reported from rainbow trout fed diets with relatively high concentrations of soybean meal or other soy products $[9,45,53,60]$.

Panserat et al. [61] observed higher VSI values in rainbow trout receiving a plant-based diet in comparison to a diet with fish meal as a primary protein source. In the current study, no differences in VSI occurred among the diets. The lack of difference in VSI may be due to the similar lipid levels among the diets, given the positive relationship between dietary lipid and VSI [62-64]. It could also be due to the small sample sizes used in this study.

Fillet protein concentrations for fish fed any of the diets was similar to that reported by Adelizi et al. [45] from trout fed a commercially-produced, fish meal-based diet. They were also similar to that reported by Yildiz [65], but less than that observed by Sealey et al. [66] for rainbow trout fed a diet containing $29 \%$ fish meal and $16 \%$ soybean meal.

\section{CONCLUSION}

In conclusion, the PepSoyGen product used in this study with amino acid supplementation support the conclusion by Yamamoto et al. [25] that fermented soybean meal in general shows promise as the main source of protein in rainbow trout diets. Additional longer-term research is obviously needed to determine the dietary adjustments needed to produce rainbow trout diets wherein PepSoyGen completely replaces fish meal with no loss of rearing performance. Additionally, research is needed to determine if any changes in intestinal morphology and function are occurring as a result of high concentrations of dietary PepSoyGen, as well as the possible immunological benefits of this PepSoyGen product. These additional studies to determine if PepSoyGen can completely replace fish meal in salmonid diets should be undertaken because of the rapid growth in global aquaculture [67] and the increased demand and market prices for limited fish meal stocks $[68,69]$.

\section{CONFLICT OF INTEREST}

The authors confirm that this article content has no conflicts of interest.

\section{ACKNOWLEDGEMENTS}

The authors thank the South Dakota Soybean Research and Promotion Council, Agriculture Experiment Station, South Dakota State University, McNenny State Fish Hatchery, South Dakota Department of Game, Fish and Parks, and the North Central Agricultural Research Laboratory, USDAARS, Brookings, South Dakota, for funding, facilities, equipment, and supplies. Furthermore, the assistance of Rici Domenici, April Gregory, Erik Klinckman, Eric Krebs, Rilie Morgan, Patrick Nero, Sharon Nichols, Mehmet Tulbek, Jill Tycz, Matt Wipf, Christine Wood, and Sarah Zimmerman is greatly appreciated. This study was also funded, in part, by Nutraferma Inc. of North Sioux City, South Dakota.

\section{REFERENCES}

[1] Storebakken T, Refstie S, Ruyter B. Soy products as fat and protein sources in fish feeds for intensive aquaculture. In: Drackley JK, Eds. Soy in Animal Nutrition; 2000: Illinois, USA, Federation of Animal Science Societies 2000; pp. 127-70.

[2] Krogdahl Å, Berg-Lea T, Olli JJ. Soybean proteinase inhibitors affect intestinal trypsin activities and amino acid digestibilities in rainbow trout (Oncorhynchus mykiss). Comp Biochem Physiol 1994; 107A: 215-9.

[3] Arndt RE, Hardy RW, Sugiura SH, Dong FM. Effects of heat treatment and substitution level on palatability and nutritional value of soy defatted flour for coho salmon, Oncorhynchus kisutch. Aquaculture 1999; 180: 129-45.

[4] Francis G, Makker HPS, Becker K. Antinutritional factors present in plant derived alternative fish feed ingredients and their effects on fish. Aquaculture 2001; 199: 197-227.

[5] Iwashita Y, Yamamoto T, Furuita H, Sugita T, Suzuki N. Influence of certain soybean antinutritional factors supplemented to a caseinbased semi purified diet on intestinal and liver morphology in fingerling rainbow trout Oncorhynchus mykiss. Fish Sci 2008; 74: 1075-82.

[6] Rumsey GL, Endres JG, Bowser PR, Earnest-Koons KA, Anderson DP, Siwicki AK. Soy protein in diets of rainbow trout: Effects on growth, protein absorption, gastrointestinal histology and nonspecific seriologic and immune response. In: Lim CE, Sessa DJ, Eds. Nutrition and Utilization Technology in Aquaculture Illionois Champaign IL: AOCS Press 1995; pp. 166-88.

[7] Burrells C, Williams PD, Southgate PJ, Crampton VO. Immunological, physiological and pathological responses of rainbow trout (Oncorhynchus mykiss) to increasing dietary concentrations of soybean proteins. Vet Immunol Immunopathol 1999; 72: 277-88.

[8] Heikkinen J, Vielma J, Kemiläinen O, Tiirola, et al. Effects of soybean meal based diet on growth performance, gut histopathology, and intestinal microbiota of juvenile rainbow trout (Oncorhynchus mykiss). Aquaculture 2006; 261: 259-68.

[9] Barrows FT, Gaylord TG, Sealey WM, Haas MJ, Stroup RL. Processing soybean meal for biodiesel production: effect of a new processing method on growth performance of rainbow trout, Oncorhynchus mykiss. Aquaculture 2008; 283: 141-7.

[10] Romarheim OH, Skrede A, Gao Y, et al. Comparison of white flakes and toasted soybean meal partly replacing fish meal as protein source in extruded feed for rainbow trout (Oncorhynchus mykiss). Aquaculture 2008; 256: 354-64.

[11] Merrifield DL, Dimitroglou A, Bradley G, Baker RTM, Davies SJ. Soybean meal alters autchthonous microbial populations, microvilli morphology and compromises intestinal enterocyte integrity of 
rainbow trout, Oncorhynchus mykiss (Walbaum). J Fish Dis 2009; 32: $755-66$.

[12] Sealey WM, Barrows FT, Smith CE, Overturf K, LaPatra SE. Soybean meal level and probiotics in first feeding fry diets alter the ability of rainbow trout Oncorhynchus mykiss to utilize high levels of soybean meal during grow-out. Aquaculture 2009; 293: 195-203.

[13] Cheeke PR, Shull LR. Natural toxicants in feeds and poisonous plants. Conneticut; AVI Publishing Company, Inc. 1985.

[14] Liener IE. Implications of antinutritional components of soybean foods. Crit Rev Food Sci Nutr 1994; 34: 31-67.

[15] Gomes EF, Rema P, Kaushik SJ. Replacement of fish meal by plant proteins in the diet of rainbow trout (Oncorhynchus mykiss): digestibility and growth performance. Aquaculture 1995; 130: 17786.

[16] Barrows FT, Stone DAJ, Hardy RW. The effects of extrusion conditions on the nutritional value of soybean meal for rainbow trout (Oncorhynchus mykiss). Aquaculture 2007; 265: 244-52.

[17] Hirabayashi M, Matsui T, Yano H. Fermentation of soybean meal with Aspergillus usamii improves zinc availability in rats. Biol Trace Elem Res 1998; 61: 227-34.

[18] Mathivanan R, Selvaraj P, Nanjappan K. Feeding of fermented soybean meal on broiler performance. Int J Poult Sci 2006; 5: 86872.

[19] Feng J, Liu X, Xu R, Lu YP, Liu YY. Effect of fermented soybean meal on intestinal morphology and digestive enzyme activities in weaned pigs. Dig Dis Sci 2007; 52: 1845-50.

[20] Kim SS, Galaz GB, Pham MA, et al. Effects of dietary supplementation of meju, fermented soybean meal, and Aspergillus oryzae for juvenile parrot fish (Oplegnathus fasciatus). Asian Aust J Anim Sci 2009; 22: 849-56.

[21] Kader MA, Koshio S, Ishikawa M, et al. Growth, nutrient utilization, oxidative condition, and element composition of juvenile red sea bream Pagrus major fed with fermented soybean meal and scallop byproduct blend as fishmeal replacement. Fish Sci 2011; 77: 119-28.

[22] Lin H, Chen X, Chen S, et al. Replacement of fish meal with fermented soybean meal in practical diets for pompano Trachinotus ovatus. Aquacult Res 2012; 44(1): 151-6.

[23] Kim SS, Pham MA, Kim KW, Son MH, Lee KJ. Effects of microbial fermentation of soybean on growth performances, phosphorous availability, and antioxidant activity in diets for juvenile olive flounder (Paralichthys olivaceus). Food Sci Biotech 2010; 19: 1605-10.

[24] Kader MA, Koshio S, Ishikawa M, et al. Can fermented soybean meal and squid by-product blend be used as fishmeal replacements for Japanese flounder (Paralichthys olivaceus)? Aquacult Res 2012; 43: 1427-38.

[25] Yamamoto T, Iwashita $\mathrm{Y}$, Matsunari $\mathrm{H}$, et al. Influence of fermentation conditions for soybean meal in a non-fish meal diet on the growth performance and physiological condition of rainbow trout Oncorhynchus mykiss. Aquaculture 2010; 309: 173-80.

[26] NRC. Nutrient requirements of fish. Washington D.C., USA: National Academy Press 2011.

[27] Buterbaugh GL, Willoughby H. A feeding guide for brook, brown and rainbow trout. Prog FishCult 1967; 29: 210-5.

[28] Association of Official Analytical Chemists (AOAC). Official Methods of for Analysis, (online version); 2009. Available from http://www.eoma.aoac.org/ [Cited $1^{\text {st }}$ May 2011].

[29] American Association of Cereal Chemists (AACC). Approved Methods of the American Association of Cereal Chemists. $10^{\text {th }}$ ed. St. Paul, MN, USA: American Association of Cereal Chemists 2000.

[30] Goede RW, Barton BA. Organismic indices and an autopsy-based assessment as indicators of health and condition in fish. In: Adam SM, Eds. Biological indicators of stress in fish. Bethseda, Maryland, USA. Symposioum 8. Am Fish Soc Symp 1990; pp. 93-108.

[31] Adams SM, Brown AM, Goede RW. A quantitative health assessment index for rapid evaluation of fish condition in the field. Trans Am Fish Soc 1993; 122: 63-73.

[32] Barton BA, Morgan JD, Vijayan MM. Physiological and conditionrelated indicators of environmental stress in fish. In: Adams SM, Eds. Biological indicators of aquatic ecosystem stress. Bethseda, Maryland, USA: Am Fish Soc 2002; pp. 111-48.

[33] Strange RJ. Field examination of fishes. In: Murphy BR, Willis DW, Eds. Fisheries techniques. $2^{\text {nd }}$ ed, Bethesda, Maryland, USA: Am Fish Soc 1996; pp 4433-66.
[34] Windell JT, Foltz JW, Sarokon JA. Method of faecal collection and nutrient leaching in digestibility studies. Prog Fish Cult 1978; 40: $51-5$.

[35] Kuehl RO. Design of experiments: statistical principles of research design and analysis. $2^{\text {nd }}$ ed. Pacific Grove, California, USA: Brookes-Cole 2000.

[36] Barnes ME, Wintersteen K, Krebs E, et al. 2010 McNenny State Fish Hatchery Annual Production Report. USA: South Dakota Department of Game, Fish and Parks 2011.

[37] Glencross BD, Booth M, Allen GL. A feed is only as good as its ingredients - a review of ingredient evaluation strategies for aquaculture feeds. Aquacult Nutr 2007; 13: 17-34

[38] Cowey CB, Degener E, Tacon AGJ, Youngson A, Bell JG. The effect of vitamin $\mathrm{E}$ and oxidized fish oil on the nutrition of rainbow trout (Salmo gairdneri) grown at natural, varying water temperatures. Br J Nutr 1984; 51: 433-51.

[39] Alanärä A. The effect of temperature, dietary energy content and reward level on the demand feeding activity of rainbow trout (Oncorhynchus mykiss). Aquaculture 1994; 126: 349-59.

[40] Kim JD, Breque J, Kaushik SJ. Apparent digestibilities of feed components from fish meal or plant protein based diets in common carp as affected by water temperature. Aquat Living Res 1998; 11: 269-72.

[41] Bureau, D, Hua PK, Harris AM. The effect of dietary lipid and long-chain n-3 PUFA levels on growth, energy utilization, carcass quality, and immune function of rainbow trout, Oncorhynchus mykiss. J World Aquacult Soc 2008; 39: 1-21.

[42] Weatherup RN, McCraken KJ. Changes in rainbow trout, Oncorhynchus mykiss (Walbaum), body composition with weight Aquacult Res 1999; 30: 305-7.

[43] de Francesco M, Parisi G, Médale F, Lupi P, Kaushik SJ, Poli BM. Effect of long-term feeding with a plant protein mixture based diet on growth and body/fillet quality traits of large rainbow trout (Oncorhynchus mykiss). Aquaculture 2004; 236: 413-29.

[44] Dabrowski K, Poczyczynski P, Kock G, Berger B. Effect of partially or totally replacing fish meal protein by soybean meal protein on growth, feed utilization and proteolytic enzyme activities in rainbow trout (Salmo gardneri). New in vivo test for exocrine pancreatic secretion. Aquaculture 1989; 77: 29-49.

[45] Adelizi PD, Rosati RR, Warner K, et al. Evaluation of fish-meal free diets for rainbow trout, Oncorhynchus mykiss. Aquacult Nutr 1998; 4: 255-62.

[46] Figueiredo-Silva AC, Rema P, Bandarra NM, Nunes ML, Valente LMP. Effects of dietary conjugated linoleic acid on growth, nutrient utilization, body composition, and hepatic lipogenesis in rainbow trout juveniles (Oncorhynchus mykiss). Aquaculture 2005; 248: $163-72$.

[47] Barrows FT, Gaylord TG, Sealey WM, Porter L, Smith CE. The effect of vitamin premix in extruded plant-based and fish-meal based diets on growth efficiency and health of rainbow trout, Oncorhynchus mykiss. Aquaculture 2008; 283: 148-55.

[48] Cheng ZJ, Hardy RW, Usry JL. Effects of lysine supplementation in plant-protein diets on performance of rainbow trout (Oncorhynchus mykiss) and apparent digestibility coefficients of nutrients. Aquaculture 2003; 215: 255-65.

[49] Cheng ZJ, Hardy RW, Blair M. Effects of supplementing methionine hydroxyl analogue in soybean meal and distiller's dried grain-based diets on the performance and nutrient retention of rainbow trout [Oncorhynchus mykiss (Walbaum)]. Aquacult Res 2003; 34: $1303-30$

[50] Holm JC, Refstie T, BØ S. The effect of fish density and feeding regimes on individual growth rate and mortality in rainbow trout (Oncorhynchus mykiss). Aquaculture 1990; 89: 222-32.

[51] Procarione LS, Barry TP, Malison JA. Effects of high rearing densities and loading rates on the growth and stress responses of juvenile rainbow trout. N Am J Aquacult 1999; 61: 91-6.

[52] Refstie S, Helland SJ, Storebakken T. Adaptation to soybean meal in diets for rainbow trout, Oncorhynchus mykiss. Aquaculture 1997; 153: 263-72.

[53] Kaushik SJ, Cravedi JP, Lalles JP, Sumpter J, Fauconneau B, Laroche M. Partial or total replacement of fish meal by soybean protein on growth, protein utilization, potential estrogenic or antigenic effects, cholesterolemia and flesh quality in rainbow trout, Oncorhynchus mykiss. Aquaculture 1995; 133: 257-74.

[54] Vandenberg GW, de la Noue J. Apparent digestibility comparison in rainbow trout (Oncorhynchus mykiss) assessed using three 
methods of faeces collection and three digestibility markers. Aquacult Nutr 2001; 7: 237-45.

[55] Glencross BD, Hawkins WE, Evans D, et al. Evaluation of the digestible value of lupin and soybean protein concentrates and isolates when fed to rainbow trout, Oncorhynchus mykiss, using either stripping or settlement faecal collection methods. Aquaculture 2005; 245: 211-20.

[56] Sachindra NM, Bhaskar N. In vitro antioxidant activity of liquor from fermented shrimp biowaste. Biores Technol 2008; 99: 9013-6.

[57] Daniels WH, Robinson EH. Protein and energy requirements of juvenile red drum (Sciaenops ocellatus). Aquaculture 1986; 53: 243-52.

[58] Kim JD, Kaushik SJ. Contributions of digestible energy from carbohydrates and estimation of protein/energy requirements for growth of rainbow trout (Oncorhynchus mykiss). Aquaculture 1992; 106: 161-9.

[59] Sakamota S, Yone Y. Effect of dietary phosphorus level on chemical composition of red sea bream. Bull Jap Soc Sci Fish 1997; 44: 227-9.

[60] Gaylord TG, Teague AM, Barrows FT. Taurine supplementation of all-plant protein diets for rainbow trout (Oncorhynchus mykiss). J World Aquacult Soc 2006; 37: 509-17.

[61] Panserat S, Hortopan GA, Plagnes-Juan E, et al. Differential gene expression after total replacement of dietary fish meal and fish oil by plant products in rainbow trout (Oncorhynchus mykiss) liver. Aquaculture 2009; 294: 123-31.

[62] Jobling M, Koskela J, Savolainen R. Influence of dietary fat level and increased adiposity on growth and fat deposition in rainbow trout, Oncorhynchus mykiss (Walbaum). Aquacult Res 1998; 29: 601-7.

[63] Company R, Calduch-Giner JA, Kaushik S, Perez-Sanchez J. Growth performance and adiposity in gilthead sea bream (Sparus aurata): risks and benefits of high energy diets. Aquaculture 1999; 171: 279-92.

[64] Yildiz M, Sener E, Timur M. Effect of seasonal change and different commercial feeds on proximate composition of sea bream (Sparus aurata). Turk J Fish Aquat Sci 2006; 6: 99-104.

[65] Yildiz M. The study of fillet quality and the growth performance of rainbow trout (Oncorhynchus mykiss) fed with diets containing different amounts of vitamin E. Turk J Fish Aquat Sci 2004; 4: 81-6.

[66] Sealey WM, Gaylord TG, Barrows FT, et al. Sensory analysis of rainbow trout, Oncorhynchus mykiss, fed enriched black soldier fly prepupae, Hermetia illucens. J World Aquacult Soc 2011; 42: 3445.

[67] FAO. The State of the World Fisheries and Aquaculture. Rome, Italy: Food and Agriculture Organization; 2009. Available from: http://www.fao.org/docrep/011/i0250e/i0250e00.HTM [Accessed 11 May 2011].

[68] Tacon AGJ, Metian M. Global overview of the use of fish meal and fish oil in industrially compounded aquafeeds: Trends and future prospects. Aquaculture 2008; 285: 146-58.

[69] Hardy RW. Utilization of plant proteins in fish diets: effects of global demand and supplies of fishmeal. Aquacult Res 2010; 41: $770-6$. 